\title{
Optimization Entrepreneurship Learning Through Contextual Teaching And Learning (CTL) Approach among High School Bussiness Student.
}

\author{
Sri Hartatik ${ }^{1}$ \\ ${ }^{1}$ Business and Management Education, SMK Negeri Tempursari \\ Email: hartatik68@gmail.com
}

Abstract:

Symptoms decrease learning motivation among students in Entrepreneurship Education evocative writer to immediately undertake innovative action in the process of study with learning approach called Contextual teaching and Learning (CTL).This Approach create with blend of learning materials to life experienced every single day, so that the learning process was meaningful. Application of CTL approach is based on the following aspects: Constructiv, Inquiry, Finding Information, Community Learning, Modeling, Reflection and Actual assessment.

Answering the question of Entrepreneurship Learning How to optimize efforts through CTL approach, it is done by taking a Class Action Research. Research subjects was undergraduate business class student of SMK Negeri Pasirian, Indonesian district. This research through three cycles for each cycle is done in three times face to face with the stages: Planning, Implementing, Observing and Reflection. At the end of the activity for each cycle the result is determined by describing the results of observation and learning outcomes.

The result was significant that the Learning Process Approach CTL capable of increasing the Learning outcome of the studenst, so that they are motivated to continue learning for the sake of next study achievement.

Keywords: Contextual teaching and learning, motivation to learn, learning outcomes

\section{Background}

Many students who think learning is a fun activity, sitting for study hour waiting to devote attention and thoughts on a subject, which is being submitted by teachers as well as being faced in study groups. This activity is almost always perceived all burden than an active effort to deepen knowledge. The decline in the passion of learning, besides due to methodological imprecision, also rooted in conventional educational paradigm that always using classical teaching methods and lectures, without ever challenging themself with a variety of methods to try. Events that stand out are less students participate and do not have the initiative and contributive both intellectually and emotionally, and it is certainly very affecting on the results learning and subject mastery.

From perspective of student learning outcomes, lately discovered that the determination of minimum score criteria (KKM) appeared to give a burden for teachers and students. For teachers this phenomenon is a challenge for them to more active, creative and innovative in selecting, preparing and delivering lessons effectively in every subject. On the other hand a lot of students who fail to meet the minimum completeness criteria in various score test was caused because students do not find the concept of learning outcomes.

Thus learning conditions causes the need for sensitivitya teacher to use a learning model that can spur students to be more active in the learning process. This phenomenon needs to be examined in an attempt to carry out learning by 


\section{International Journal for Social Studies Available at https://edupediapublications.org/journals

ISSN: 2455-3220

using appropriate methods that empower students fully in learning.

Reflection on the results of preliminary observations made to the data of student achievement on the subjects of entrepreneurship in XII class A Bussiness Study Program SMK Pasirian in 2012, amounting to 34 students consisting of male students as many as 14 people, and as many female students 20 people, it is known that they must meets the criteria of completeness with $\geq 7,0$ score value is 14 students or $41 \%$ and who have not reached the value criterion is 20 students or $59 \%$. This condition shows that the achievement of incompetence is much greater than the competent so that a teacher must analyze.

The above issues be interesting to observe how the efforts of teachers to implement the learning process with appropriate methods. And for that one method of learning which allows students to learn optimally to achieve the targets set minimum completeness criteria is the method of Contextual Teaching and Learning (CTL).

This learning method is a method of learning to expedite the acquisition of learning outcomes. Through the method of Contextual Teaching and Learning (CTL), the method is believed, will be able to raise the activities of the students in the learning process which in turn will bring, a paradigm shift that lesson prossess into a pleasant subject.

Digitally Contextual Teaching and Learning method allows the creation of a learning process that is quiet as well as fun.

Contextual learning encourages students to understand the nature, meaning and benefits of learning, so that students are motivated to constantly learn and keep learning. The condition tenwujud when students begin to realize what they need in this life and how efforts to make it happen. Basically, all students have the curiosity include the potential to satisfy his curiosity. The task of the teacher in this case is to condition a pleasant learning environment in order to arouse the curiosity of all students so that they are motivated to learn. Teachers demanded to link the material being taught with real environmental conditions. Through the method of Contextual Teaching and Learning Entrepreneurship expected learning process in SMK Pasirian be more optimal.

Based on the above background, the problem in this study can be formulated as follows "Is Study Implementation Method Contextual Teaching and Learning (CTL) on entrepreneurship learning in class XII SMK Bussiness Studies can optimize learning outcome and motivation?"

\section{LITERATURE REVIEW \\ Role of Teachers in Learning}

Sandjaya (2005: 69) states in the implementation of peinbelajaran, learners are assisted by educators involved in the learning process. This process includes the activities for setting up the facility or teaching aids, receive information about the material / learning materials and learning procedures, discuss the material / learning materials and the exchange of experiences and opinions in discussing the matter or solve problems.

Teachers in this case is required to be able to involve students in developing or modifying learning activities, so that learning becomes more meaningful. Teachers demanded to be able to associate the material in the curriculum with the real environment, so that students feel that learning activities have benefits in everyday life. Presumably that is the capital to be able to optimize learning Entrepreneurship to become subjects not drab, but it will be more like the students.

Optimization is the process, optimizing the way or deeds. Optimizing means making the most good, highest or most profitable. According to the Development Team Language Dictionary (1994: 705). While learning by Sudjana (2005: 8) is any attempt systematic and deliberate by educators to create the conditions so that learners perform learning activities. In this activity occurs educational interaction between learners by educators. So learning activities characterized by a deliberate attempt, planned and systematically carried out by educators to help students in learning activities.

Meanwhile, Prof. DR. HA Wahab Aziz, MA. (2003: 2.48) in this case states that learning is a systematic effort to be able to realize the goal of optimally according to the circumstances (teachers, students, facilities and environment). Systematic efforts are reflected in the learning plan (what is written and what is thought by teachers) and in the learning process (there is a real happening in the learning interactions). In the model learning objectives (Objectives Model) all learning activities should depart from the objectives and oriented towards achieving goals, or in other words that the Education Process, patterned "of purpose, through learning for the purpose of" this pattern that looks like a chart illustrated below:

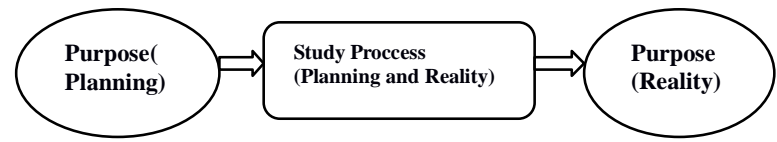

Figure 1. Pattern of Purpose 
From the chart above shows that to achieve the goal as the reality of real life, the role of learning is so important. Therefore the learning process should be optimized. Thus optimizing the learning process is a process or way to make learning which contains a mix of teachers plan and the reality of real life, leading to the best level, the highest or most profitable level.

Methods of Contextual Teaching and Learning (CTL) method is one of the important elements in the learning activities. Selection of the appropriate method will clearly affect the achievement of learning objectives. According to Abdul Madjid (2006: 136-137) methods in education is the way taken by or used in an attempt to provide insight on the students. In this case to consider is the overall accommodation to the principles of learning activities, Such as:

a. Centered on the student (student oriented)

b. Learning by doing (learning by doing)

c. Develop social abilities (learning to live together)

d. Develop curiosity and imagination

e. Develop creativity and problem-solving skills.

Contextual Teaching and Learning, is essentially an implementation and determination of learning materials tailored to regional characteristics. Students will learn well when what is learned related to what is already known and with the activities or events that occur around them.

According Mulyasa (2006: 102) Contextual Teaching and Learning is a learning concept which emphasizes the links between the world of learning materials with students in real life, so that students will be able to connect and apply $\cdot$ competency learning outcomes in everyday life. Students will feel the importance of learning and will gain a deep meaning to what is learned. The same thing also expressed by Sanjaya (2006: 109) that Contextual Teaching and Learning is a learning approach that emphasizes the process of involvement of students in full to be able to find the material studied and relate them to real life situations, thus encouraging students to apply them to life in society, Thus, students will become increasingly aware that the real education is self needs, so they are motivated to learn optimally, without feeling forced, for example due to pressure teachers, due to the pressure of parents or other things.

From the above definition, seen three basic concepts Contextual Teaching and Learning, can be describe: a. Emphasized the involvement of students in finding the material, considering.

b. This learning experience to apply directly.

c. Encourage students to find an association between the materials studied to be more meaningful that is not easily forgotten.

d. Encourage students to be able and capable to apply them in life, that is to say fun study contextual expect students in addition to understand so that they are motivated to learn optimally, without feeling forced, for example due to pressure teachers, due to the pressure of parents or other things.

Regarding the conducive learning environment, Mulyasa (2006: 103) argues about the importance of learning in contextual learning environment, such as:

1) Study was initiated and environmentally effective student-centered learning.

2) Learning should be centered on how students use their new knowledge. Learning strategy is more important than the result.

3) Feedback is very important for students.

4) Growing a learning community in the form of group work, it is important. Contextual Teaching and Learning (CTL) have the characteristics should be cooperation, mutual support, excited, passionate learning, integrated learning, using a variety of sources, students are active, fun, not boring, sharing with friends, students' critical and creative teacher.

One thing that needs to be cultivated in order contextual learning can be implemented in line with expectations is how the creativity of teachers in preparing a learning program itself. For this Nurhadi (2004: 148-149) gives the key to success in contextual learning, which is as follows

1) Real Word Learning

2) Focusing on real experience

3) Think high level

4) centered on the students

5) Students are active, critical and creative

6) knowledge meaningful in life

7) Education or education,

The Aspects of Contextual Teaching and Learning In contextual learning, teachers are required capable of creating an enjoyable learning, so be creative in selecting methods for the learning process can be effective and conducive. For that teachers should integrate and implement various basic components in the learning process. Nurhadi (2004: 31-51) states: Some aspects that underlie the application of contextual learning in the classroom is: 
"Constructivism (Constructivism); inquiry (Questioning); Found (Inquiry); community learn (Leanrning Comununity); Modeling (Modeling); Reflections (Reflection); and the actual votes (Authentic assessment) "Aspects Constructivism (Constructivism), meant that the students will be learning more meaningful by working alone, find yourself and construct own knowledge and new skills, on a small scale or limited. Deep understanding gained through meaningful learning experiences.

Aspects of inquiry (Questioning) used to train and assess students' ability to think critically. Inquiry as a learning tool to develop the nature want to know the students, encouraging students to learn something as well as directing students to obtain more information. Because the questioning skills need to be trained and socialized.

Aspect (Inquiry),implemented to achieve the desired competence. By using and developing critical thinking skills, students are expected to actually be able to understand the concept and formulate a theory either Individually or in groups.

Aspects of Learning Community (Learning Community), intended to create a learning environment that emphasizes community-kelotripok learning in groups. Digitally so students have many opportunities to share experiences, to dialogue, to cooperate with others. The creation of a learning society will obviously bring a better impact than to learn individually.

Aspects of Modeling (Modeling), is to show the model as an example of learning. The model in question can be objects, teachers, other students, etc. The innovation works. This aspect will express the idea of thought, demonstrating how the student wants to learn, and do what they want so that the students moved to do so.

Aspects of Reflection (Reflection), it is necessary to make students feel that today they learned and gained something useful. Reflection is done at the end of a meeting with a few statements such as: ways of thinking about what they have learned; examine and respond to the incident; aktivifas and experience; note what they have learned and feel the new ideas.

Actually aspect Ratings (Authentic Assessment), which is doing the actual assessment of the student as a result of the study. final Scoring done by looking from various sources and in various ways, for example by observing the activity of assessment processes, skills, discipline individual students sealama learning takes place. Which is often done in this respect is a teacher carrying out post test either in writing or orally. It is important to measure the knowledge and skills of students after implementing the learning process. directing students to obtain more information. Because the questioning skills need to be trained and socialized.

Aspect (Inquiry), implemented to make everything to be desired. By using and developing critical thinking skills, students are expected to actually be able to understand the concept and formulate a good theory in every groups.

Aspects of Learning Community (Learning Community), intended to create a learning environment that emphasizes learning community in groups. Thus, students have many opportunities to share experiences, to dialogue, to cooperate with others. The creation of a learning society will obviously bring a better impact than the study itself.

Aspects of Modeling (Modeling),namely by showing the model as an example of learning. The model in question can be objects, teachers, other students, the work of innovation and Aspect will familiarize the idea under consideration, demonstrating how the student wants to learn, and do what they want so that the students moved to do so.

Aspects of Reflection (Reflection), is given so that students have initiative what they learn and gain something usefull. Reflection is done at the end of a meeting with a few statements such as: ways of thinking about what they have learned; activity and experience; note what they have learned and feel the new ideas.

And last aspect Ratings (Authentic Assessment), which is doing valuable assessment of the student as a result of learning.

\section{Methods}

This research included Action Research class and using quantitative descriptive method. Setting Class Action Research study was conducted at SMK Pasirian at Jalan Raya Condro Pasirian, Indonesian district. Meanwhile, the implementation time of the first semester of the Academic Year 2012-2013. The research subjects taking a class XII A Bussiness Study Program, amounting to 34 students, comprised and 14 male students and 20 female students. Is classified as a class has more potential than the other classes. But the application of varied methods that have been 
applied by teachers was less evocative activity of students in the learning process.

Even when the occasional use lectures, students were less enthusiastic and quickly saturated. Only a few students are indeed proactive and creative responded positively during the learning takes place, by asking a few questions. Regarding the socio-economic background of students, they generally come from middle class families and the majority of farmers.

Therefore three step was attempted to gain more best result to this approach, as can see as below Program.

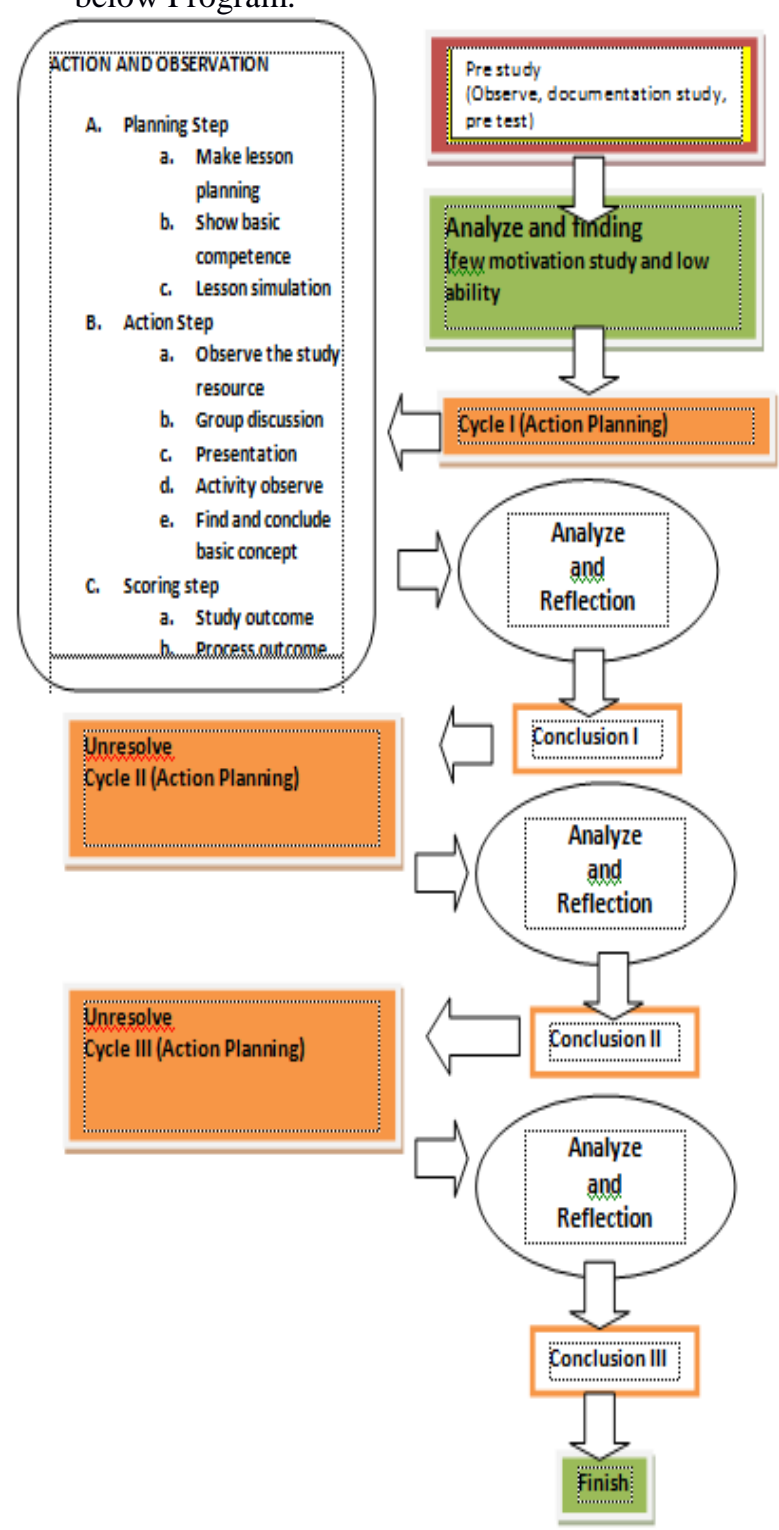

Figure 3. Basic three step concept of action research

\section{Results and Discussion}

Results of this Class Action Research include three cycles, each cycle was conducted in three sessions, with an allocation of $2 \times 45$ minutes for each meeting. Learning process focused on achieving the Basic Competence: Ability to analyze the place of business and human resource placement. Cycle one as probing whether the Learning Process Approach Contextual Teaching and Learning (CTL) can run as expected. Initially in the delivery of basic competencies that must be achieved. Continued division of the group at once assign tasks to each group.

Students start looking for the source material, and this can be implemented in the classroom, in the library or the environment within the school. Thirty minutes later in the classroom the students carry out discussion groups to formulate a theory in accordance with their respective duties. This activity lasted up to an hour lesson ends and each group presented the results of work. At first glance that seems a learning atmosphere at the meeting of the cycle one, very fun, beginning to look for teamwork. They are trying to find and integrate various sources of information as to find a concept.

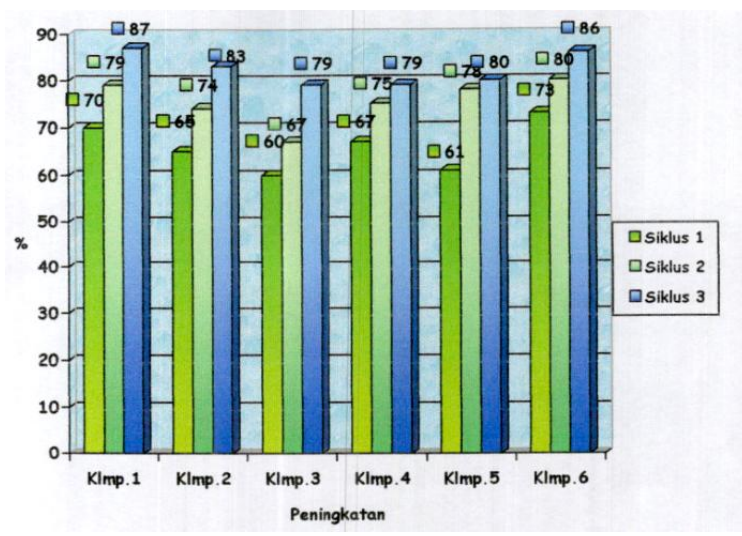

Figure 4. The increment result lesson outcome

At the second meeting held classroom discussions, each group had the opportunity to present their work. Learning atmosphere looks increasingly showing progress. Began to appear courage to convey the concept, maintaining the theory, ask questions and arguments. As for the third meeting is divided into two activities, the first sixty minutes to continue class discussions and menyamaan perception, summed up the results of work during the Learning Process in cycle one. Furthermore, the next thirty minutes of Post Test conducted to ascertain whether the basic competencies have been mastered.

Learning Process Implementation for the second cycle, not much different from the 
implementation of the first cycle, there is increasing emphasis on just a little bit, especially improvements in finding and mengkontruksikan theory. Cycle two expected no increase in the quality of learning process. Likewise for the third cycle, is intended as a complement that is able to prove that through the Learning Process Approach CTL activity can stimulate students in finding knowledge, the courage to ask, capable of critical thinking, which in turn raise awareness of the benefits of learning.

Each activity in the learning process is observed once the assessment. Implementation is done by a teacher as an observer (Collaborator).

\section{Discussion}

Learning Process Based on the results, as the description above, shows that the Entrepreneurship Learning Process through Contextual Teaching and Learning approach proved to be very effective tmtuk applied. It is evident from the significant quality improvement between the first cycle, second cycle and third cycle. In Table 3 shows, average increase in the quality of learning process between the first cycle and the second cycle, reaching $7.5 \%$, while the second cycle and the third cycle, the average increase reached $8.33 \%$.

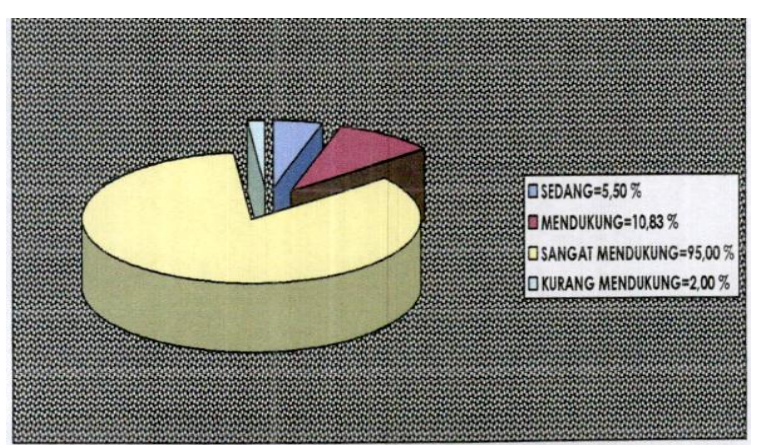

Figure 5. Prosentase supported teacher to CTL

\section{Conclusion}

Conclusions and discussion results obtained some conclusions as the findings in this study as well as the answers to the formulation of the problems that occur in business students SMK Pasirian. Conclusion The results of the study look like a learning process through Contextual Teaching and Learning approach is proven to motivate and increase the student activity, so the learning activities to be optimal, student interest is very supportive of success in applying the approach Contextual Teaching and Learning in the Learning Process. Optimizing the learning activities turned out to bring a positive influence that rising Student Achievement.

\section{suggestion}

Recommendations With the completion of this classroom action research activities as well as attention to the above conclusion, the researchers convey the following suggestions to envoy more class to clarified more result. Best result came from many research in one approach.

\section{References}

Amyx, D., Bhuian, S. \& Shows, G. 2015. Customerrelationship salespeople Behaviors Influence of entrepreneurial salespeople. Bussiness Intelligence \& Planning, $\quad 34 \quad$ 586-604, (https://doi.org/10.1108/MIP-09-2015-0170).

Basu, A. \& Goswami, A. 1999. South Asian entrepreneurship in Great Britain: factors in $\mathrm{fl}$ uencing growth. International Journal of Entrepreneurial Behavior \& Research, 5 (5), 251-75.

Battilana, J., B. \& Boxenbaum Leca, E. 2009. How Institu- tions Actors Change: Towards a Theory of Institutional Entrepreneurship. Academy of Management Annals, 3, 65-107.

Forbes, DP \& Kirsch, DA 2011. The study of emerging industries: Recognizing and responding to some central problems. Journal of Business Venturing.

Gibb, A. 2002. In pursuit of a new 'Entrepreneurship' and 'entrepreneurship' paradigm for learning: creative destruc- tion, new values, new ways of doing things and new combinations of knowledge. International Journal of Management Reviews, 4 (3), 233-269.

Guba, Egon, G and Yvonna SL 1981. Effective Evaluation, San Francisco: Jossey-Bass Publishers.

Harris, C., Jenkins, M. \& Glaser, D. 2006. Gender differences in risk assessment: why do women take fewer risks than men ?. Judgment and Decision Making, 1 (1), 48-63.

Ireland, R., Covin, J. \& Kuratko, D. 2009. "Conceptualizing corporate entrepreneurship strategy", Entrepreneurship Theory and Practice, 33 (1), 19-46. 
Johnson, J. \& Powell, P. 1994. Decision making, risk and gender: managers are different ?. British Journal of Management, 5 (1), 123-138.

Karp, T. 2006. The Inner Entrepreneur: constructivistic View of Entrepreneurial Reality Construction. Journal of Change Management, 6 (3), 291-304.

Kirkley, W. 2016. Entrepreneurial Behavior: The Role of Values. International Journal of Entrepreneurial Behavior \& Research, 22 (3), 290328. (https://doi.org/10.1108/IJEBR-02-2015-0042, Accessed March 7, 2018.

Liu, G, Joyce Ko, W., Ngugi, I. \& Takeda, S. 2017. Proactive entrepreneurial behavior, market orientation, and innovation outcomes: a study of small- and medium-sized manufacturing firms in the UK. European Journal of Bussiness, (https://doi.org/10.1108/EJM-11-2016-0663)

Lofland, J. \& Lyn H. 1984. Analyzing Social Settings: A Guide to Qualitative Observation Analysis, Belmont, Cal .: Wads Worth Publising Company.

Lumpkin, G. \& Dess, G. 1996. Clarifying the entrepreneurial orientation construct and linking it to performance. Academy of Management Review, 21 (1), 135-172.

Man, T. \& Lau, T. 2005. The context of entrepreneurship in Hong Kong. Journal of Small Business and Entrepreneurship Development, 12 (4), 464-81.

Martin, G. \& Staines, H. 1994. Management competencies in small fi rms. International Journal of Management Development, 13 (7), 23-34.

Mezias, S. \& Kuperman, J. 2001. The community dynamics of entrepreneurship: The birth of the American movie industry, from 1895 to 1929. Journal of Business Venturing, 16, 209-233.

Moleong, L. 2010. Qualitative Research Methodology. Bandung: PT. Youth Rosdakarya.

Madjid, Abdul. 2006 . Perencanaan Pembelajaran Mengembangkan Standar Kompetensi Guru. Bandung : Remaja Rosdakarya.

Morris, M. \& Paul, G. 1987. The relationship between entrepreneurship and Bussiness in established firms. Journal of Business Venturing, 2 (3), 247-259.
Mulyasa. 2003 . Kurikulum Berbasis Kompetensi, Konsep, Karakteristik dan Implementasi. Bandung : Remaja Rosdakarya.

Mulyasa, 2006. Menjadi Guru Profesional Menciptakan Pembelajaran Kreatif dan Menyenangkan. Bandung : Remaja Rosdakarya.

Nurhadi. Yasin, Burhan Gerrad, Agus. ( 2004 ). Pembelajaran Kontekstual dan Penerapan dalam KBK. Malang : Universitas Negeri Malang.

Popay, J. \& Williams, G. 1998. Qualitative research and evidence-based healthcare. Journal of the Royal Society of Medicine, 35, 32-37.

Powell, M. \& Ansic, D. 1997. Gender differences in risk behaviors in financial decision-making: an experimental analysis. Journal of Economic Psychology, 18 (6), 60-628.

Malang Regency Government Portal profile. (On line), (http://turen.malangkab.go.id/?page_id=5), Accessed March 8, 2018.

Reijonen, H. \& Komppula, R. 2007. Perception of success and its effect on small firm performance. Journal of Small Business and Entrepreneurship Development, 14 (4), 689-701, (https://doi.org/10.1108/14626000710832776),

Accessed March 15, 2018.

Reynolds, P., Hay, M., Bygrave, W., \& Autio, E. 2000. Global Entrepreneurship Monitor: 2000 Exwcutive Report, Kauffman Center for Entrepreneurial Leadership at the Ewing Marion Kauffman Foundation, Kansas City, MO.

Shane, S. \& Venkataraman, S. 2000. The promise of entrepreneurship as a fi eld of research. Academy of Management Review, 25, 217-226.

Sorge, A., Hartmann, G., Warner, M. \& Nicholas, I. 1982. New Technology and Craftsmen's Skills in Great Britain and West Germany. Employee Relations, 4 (5), 21-23, (http://dx.doi.org/10.1108/eb055001). 
Sanjaya, Wina. ( 2006 ). Pembelajaran dalam Implementasi Kurikzdum Berbasis Kompetensi. Jakarta : Kencana Prenada Media Group.

Sudjana. ( 2005 ). Metoda dan Teknik Pembelajaran Partimpatif. Bandung : Falah Production.

Tim Penyusun Kamus Bahasa. 1994 ). Kamus Bahasa Indonesia. Jakarta : Rineka Cipta.

Sugiyono. 2010. Quantitative Research Methods, Qualitative and R \& D Bandung: Alfabeta.

Thurik, R. and Wenneker, S. 2004. Entrepreneurship, small business and economic growth. Journal of Small Business and Entrepreneurship Development, $11 \quad(1)$, 140-149, (https://doi.org/10.1108/14626000410519173).

Zampetakis, 1. \& Moustakis, V. 2007. Entrepreneurial behavior in the Greek public sector. International Journal of Entrepreneurial Behavior \& Research, 13 (1), $19-38$ (http://doi.org/10.1108/13552550710725165). 